\title{
Evaluation of the Influence of Ambient Temperature on the Performance of the Trans-Amadi Gas Turbine Plant
}

\author{
Emughiphel Nelson Igoma ${ }^{1,2}$, Barinaada Thaddeus Lebele-Alawa², John Sodiki² \\ ${ }^{1}$ Department of Marine Engineering, Yaba College of Technology, Yaba, Nigeria \\ ${ }^{2}$ Department of Mechanical Engineering, Rivers State University of Science and Technology, Port Harcourt, Nigeria \\ Email: eniomarineoilandgas@gmail.com, lebelealawa@yahoo.com, jisodiki_partners@yahoo.com
}

How to cite this paper: Igoma, E.N., Lebele-Alawa, B.T. and Sodiki, J. (2016) Evaluation of the Influence of Ambient Temperature on the Performance of the Trans-Amadi Gas Turbine Plant. Journal of Power and Energy Engineering, 4, 19-31. http://dx.doi.org/10.4236/jpee.2016.411002

Received: October 14, 2016

Accepted: November 21, 2016

Published: November 24, 2016

Copyright $\odot 2016$ by authors and Scientific Research Publishing Inc. This work is licensed under the Creative Commons Attribution International License (CC BY 4.0).

http://creativecommons.org/licenses/by/4.0/

\section{Abstract}

This paper examines the effects of ambient temperature on the Trans-Amadi gas turbine power station Phase II. The investigation took thirteen (13) months (January 2012 to January 2013) during which plant data were monitored and operational Logsheets like turbine logsheets, plant-auxiliaries' logsheets and generator logsheets were studied. The gas turbine (GT) that was under investigation was GT-2: MS5001 Nuovopignone with designed installed capacity of 25.0 Megawatts (MW). The result of the study shows that a $1^{\circ} \mathrm{C}$ rise of the ambient temperature is responsible for the following: $0 \%-0.12 \%$ decrease in the power output, $0 \%-0.12 \%$ increase in the power differential, $0 \%-1.17 \%$ decrease in the thermal efficiency, $0 \%-27.18 \%$ increase in the heat rate and $0 \%-3.57 \%$ increase in the specific fuel consumption. An ambient temperature of $30^{\circ} \mathrm{C}$ is found to yield minimal fuel consumption.

\section{Keywords}

Ambient Temperature, Performance, Gas Turbine, Power and Thermal Efficiency

\section{Introduction}

The gas turbine in its most common form is a heat engine operating by means of series of processes consisting of compression of air taken from the atmosphere, increase of gas temperature by constant-pressure combustion of fuel in the air, expansion of hot gases and discharge of the gases to the atmosphere. It is thus similar to the spark ignition (S.I) and internal combustion (I.C) engines in working medium but is akin to the steam turbine in its aspect of the steady flow of the working medium [1] [2] [3]. The gases expand during the work process and finally exhaust outside. The only difference 
is that, instead of the reciprocating motion as in the case of the internal combustion (I.C) engines, the gas turbine uses a rotary motion [4].

The axial-thrust responses due to gas turbine rotor blade distortions have been studied [5]. The study showed that the axial thrust imposed on the shaft of a gas turbine depends upon its rotor blade inlet inclination to the turbine's axial direction. This inclination can change due to the distortions resulting from the blade tip rubbing, erosion and corrosion, aging, fouling and thermal-fatigue cracks. Meanwhile, relevant influential parameters of the gas turbine were measured while in operation. Theoretical predictions for the behavior of the same turbine were obtained from computer simulations. The results of both measured parameters and theoretical prediction parameters were compared which showed qualitative correspondence. The rotor blade profile distortions result in significant increases in the axial thrust on the compressor which adversely affects the gas turbine's thermodynamic performance, reliability and operational life.

The optimization performance analyses of a gas turbine plant were conducted [6]. Their investigation presented exergy based analysis and power inlet temperature drop practical approaches in the optimization of the plant exergetic efficiency. An investigation of the exergetic efficiency and destruction in the plant showed that were largely affected by variation in the power turbine inlet temperature. Precisely, for $15 \%$ decrease in the power inlet temperature an $83.71 \%$ in exergetic efficiency was achieved.

The effect of compression ratio on the performance of combined cycle gas turbine was investigated [7]. The work used a complete model of combined cycle gas turbine to check the effect of the gas turbine compression ratio. The overall efficiencies of the combined cycle gas turbine were found to be higher than those of the single cycle gas turbine plant, by utilizing a MATLAB Simulation model.

The influence of Variation of Power Turbine Inlet Temperature on Overall Turbine Efficiency was studied [8]. In their investigation, data were obtained from control room logsheets for the period of about sixty (60) weeks and investigated. Key parameters of pressure, temperature and power output were considered during the data collection. Appropriate thermodynamic relations and principles were used in the determination of data that could not be directly collected from the control room logsheets. The values obtained show that as the power turbine inlet temperature drops from $843.44 \mathrm{~K}$ to $779.05 \mathrm{~K}$; the power output rises from $94.65 \%$ - 94.76\% while the power output rises also from 13.28 MW - 15.52 MW. Furthermore, irreversibility drops from 63.22\% $61.96 \%$. These have shown that operating a gas turbine power plant at lesser or lower power turbine entry temperature as the systems tends to reach its rated capacity gives a better performance.

The investigation of the effect of Evaporative Cooling on the Performance of a Gas Turbine Plant located in Bayelsa State, Nigeria has been done [9]. The investigation critically and holistically examined the influence of an evaporative cooler on turbine inlet air and how the turbine reacts to the compressor inlet temperature. The work made use of the actual operational conditions like compressor inlet temperature and 
relative humidity in the determination of the following: compressor work, turbine network, specific fuel consumption and the thermal efficiency of the plant. The findings showed that as the compressor inlet temperature was lowered, the compressor work reduces, the turbine network increases, specific fuel consumption drops and the efficiency of the plant increases appreciably. Furthermore it was seen that the evaporative cooling decreased the compressor inlet temperature by $2.4^{\circ} \mathrm{C}$ leading to a rise of about $0.14 \%$ and $2.02 \mathrm{KJ} / \mathrm{Kg}$ in the efficiency and network respectively and also 0.002 $\mathrm{Kg} / \mathrm{KWh}$ decrease in the specific fuel consumption. Hence, the investigation shows that gas turbine plants work well in temperate region than tropical. Therefore, to enhance the performance of the existing gas turbine plants in high temperature climates, retrofitting of an air cooler that will always reduce the temperature back or close to the design temperature before compression is necessary.

The Thermodynamic Performance Analysis of a Gas Turbine in an Equatorial Rain Forest Environment has been done [10]. In the study, steady state monitoring and direct collection of data from MKIV speedtronics system was done. The variation of operating conditions( ambient temperature, compressor discharge temperature, turbine inlet temperature, exhaust temperature and mass flow rate) on the performance of the gas turbine thermal efficiency, net power output, heat rate, specific fuel consumption and compressor work were investigated utilizing various appropriate thermodynamic equations and formulae. The results show that $1^{\circ} \mathrm{C}$ rise of the ambient temperature will cause the following: $1.37 \%$ drop in the net power output, $1.48 \%$ rise in the power drop, $1.49 \%$ drop in the thermal efficiency, $2.16 \%$ rise in the heat rate, $2.17 \%$ rise in the specific fuel consumption and $0.3 \%$ rise in the compressor work. Moreover, the thermal efficiency drops by $0.006 \%$ for every $1 \mathrm{Kcal} / \mathrm{KWh}$ rise in the heat rate and the heat transfer in the hot gas part was found to rise by $0.16 \%$ for every $1^{\circ} \mathrm{C}$ rise in the compressor inlet temperature. The study revealed that the gas turbine had a large decrease in the power output due to the influence of site parameters different from design parametric data.

The present study is on the effects of ambient temperature on the Performance of the Trans-Amadi Gas Turbine Power Station Phase II: (GT)-Unit II: MS5001 Nuovopignone Engine. The energy balance in the combustion chamber was utilized to compute the turbine inlet temperature and study the effect of the ambient temperature on the operating parameters like thermal efficiency, specific fuel consumption and heat rate.

\section{Materials and Methods}

The research methodology involved collection of data from actual plant operational logsheets: turbine logsheets, plant-auxiliaries logsheets and generator logsheets for the months of January 2012 to January 2013. Parameters which could not be directly measured or determined were derived utilizing appropriate thermodynamic equations and principles [11] [12].

The primary parameters considered during the data collection are the pressures, temperatures and mass flow rates at various points in the gas turbine. However, in the 
evaluation and treatment of the data, statistical methods were used to calculate the mean values of daily parameters. This was done for every month that is under consideration and the average was taken at the end of each month. The actual performance of the power plant over the period of its installation was determined from their average parameters: inlet pressures, outlet pressures, inlet temperatures, mass flow rates, outlet temperatures and compressor works.

The Brayton (Joule) cycle is the thermodynamic cycle upon which this gas turbine operates and can be analysed using Figure 1:

By applying first law of thermodynamics for an open system, we have:

$$
\dot{Q}-\dot{W}_{\text {SHAFT }}=\sum_{\text {in }} \dot{m}\left(h+\frac{v^{2}}{2}+g z\right)_{\text {in }}-\sum_{\text {out }} \dot{m}\left(h+\frac{v^{2}}{2}+g z\right)_{\text {out }}
$$

For the purpose of this analysis, the kinetic energy $\left(v^{2} / 2\right)$ and the gravitational potential energy $(g z)$ are not significant factors and can be neglected.

The First Law becomes:

$$
0=\dot{Q}-\dot{W}_{\text {SHAFT }}+\dot{m}\left(h_{\text {in }}-h_{\text {out }}\right)
$$

Mathematically, we have the following from Figure 1:

Heat Supplied or Heat Added:

$$
\dot{Q}_{1}=\dot{m}_{a} C_{p}\left(T_{3}-T_{2}\right)
$$

The Heat Rejected or Heat Removed will be;

$$
\dot{Q}_{2}=\dot{m}_{a} C_{p}\left(T_{4}-T_{1}\right)
$$

The Turbine Work is equal to:

$$
\dot{W}_{T}=\dot{m}_{p} C_{p}\left(T_{4}-T_{3}\right)
$$

The Net Power Output is the power generated by the generator and is given as:

$$
\dot{W}_{N e t}=\dot{W}_{T}-\dot{W}_{C}
$$

Therefore, the energy balance in the combustion chamber is expressed as [15]:

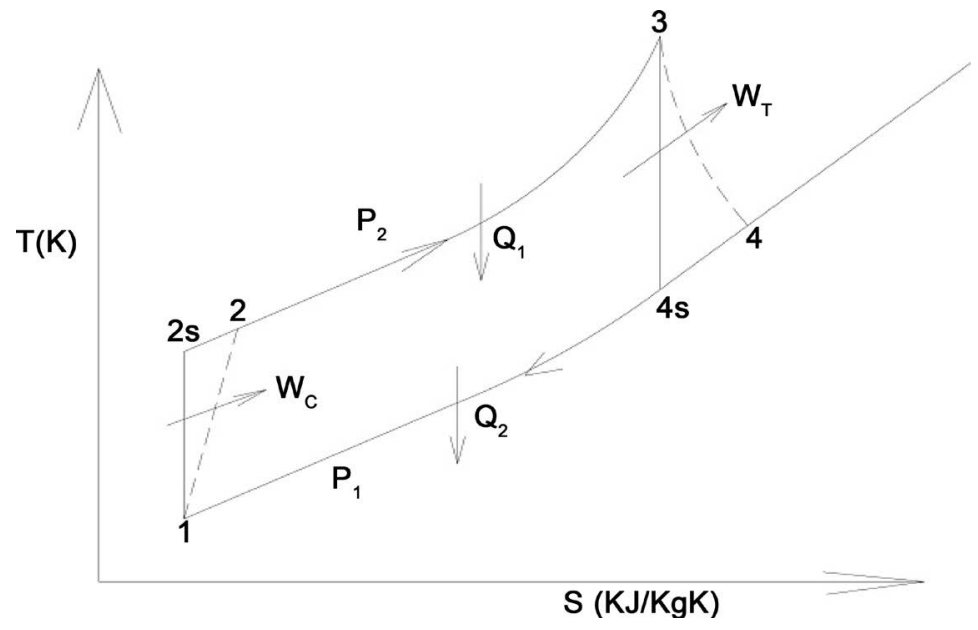

Figure 1. T-S Diagram for Brayton Cycle [13] [14]. 


$$
\dot{m}_{a} C_{p a} T_{2}+\dot{m}_{f} \times L H V+\dot{m}_{f} C_{p f} T_{f}=\left(\dot{m}_{a}+\dot{m}_{f}\right) C_{p g} \times T_{3}
$$

where: $\mathrm{LHV}=47541.6 \mathrm{KJ} / \mathrm{Kg}[16]$.

After manipulating Equation (11); the fuel ratio ' $f$ ' is expressed as:

$$
f=\frac{\dot{m}_{f}}{\dot{m}_{a}}=\frac{C_{p a} \times T_{3}-C_{p a} T_{2}}{L H V-C_{p g} T_{3}}
$$

The Total Heat Supplied is expressed as [10]:

$$
\dot{Q}_{\text {added }}=\left(\dot{m}_{a}+\dot{m}_{f}\right) \times C_{p a}\left(T_{3}-T_{2}\right)=\dot{m}_{f} \times C V
$$

Meanwhile, the Isentropic Efficiency of the Turbine will be:

$$
\eta_{t s}=\frac{\text { Actual Work }}{\text { Isentropic Work }}=\frac{T_{3}-T_{4}}{T_{3}-T_{4 s}}
$$

Therefore, $T_{4 S}$ can be defined as:

$$
T_{4 s}=\frac{T_{3}}{\left(\frac{P_{2}}{P_{1}}\right)^{\frac{\gamma-1}{\Upsilon}}}
$$

$P_{2}=P_{3}$ and $P_{4}=P_{4}$.

Turbine Pressure Ratio $=P_{3} / P_{4}$ and the Compressor Pressure Ratio $=P_{2} / P_{1}$.

The Compressor Work is calculated from the mass flow rate and enthalpy change across the compressor as follows:

$$
\dot{W}_{c}=\dot{m}_{a} C_{p a}\left(T_{2}-T_{1}\right)=\rho_{a} v_{a} C_{p a}\left(T_{2}-T_{1}\right)
$$

Thermal Efficiency: The gas turbine efficiency is the percentage of the total fuel energy input that appears as the net work output of the cycle.

$$
\eta_{t h}=\frac{\text { Net Work }}{\text { Total Heat Supplied }}=\frac{\dot{W}_{\text {Net }}}{\dot{Q}_{\text {Added }}}
$$

where: the network is the power output and is given by Equation (6).

Specific Fuel Consumption: The ratio of fuel used by a machine to a certain force such as the amount of power in the machine produced. And it can be determined by the equation:

$$
S F C=\frac{3600 \times \dot{m}_{f}}{\dot{W}_{\mathrm{Net}}}
$$

Heat Rate: This is a measure used to determine how efficiently a generator uses heat energy. It can be expressed as:

$$
H R=\frac{\text { Heat Supplied }}{\text { Power Generated }}=\frac{1}{\eta_{t h}}
$$

Stoichiometric equation: This is the ideal combustion process in which minimum amount of air (Stoichiometric or theoretical air) is needed to completely burn a fuel.

$$
\mathrm{C}_{m} \mathrm{H}_{n}+\left(m+\frac{n}{4}\right) \mathrm{O}_{2}+3.76\left(m+\frac{n}{4}\right) \mathrm{N}_{2} \rightarrow m \mathrm{CO}_{2}+\frac{n}{2} \mathrm{H}_{2} \mathrm{O}+3.76\left(m+\frac{n}{4}\right) \mathrm{N}_{2}
$$


Also the Specific Fuel Consumption can also be calculated with the following formula:

$$
S F C=\frac{3600}{A F R \times \dot{W}_{\text {Net }}}
$$

Therefore, Air Fuel Ratio:

$$
A F R=\frac{L H V}{\dot{Q}_{\text {Added }}}
$$

\section{Results and Discussions}

\subsection{Results}

The parameters in Table 1 were obtained directly from the operational manual of MS5001 Nuovopignone Gas Turbine. The values in Table 2 are the compressor exit temperature, exhaust temperature, power output or average power generated, compressor exit pressure and mass flow rate of the fuel which were obtained directly from the turbine logsheets, generator logsheets and plant-auxiliaries logsheets, while the values for turbine inlet temperature, compressor work, turbine work, net work, total heat supplied or added, air fuel ratio, thermal efficiency, specific fuel consumption and heat rate were obtained by calculation: using Equations ((5), (6), (8), (9), (12), (13), (15), (17) and (18)) respectively. Table 3 contains the values of the actual parameters such as power output (average power generated), thermal efficiency, specific fuel consumption and heat rate compared to their respective design values [10].

Finally, the effects for every $1^{\circ} \mathrm{C}$ rise in the ambient temperature with the power output, power differential, thermal efficiency ratio, specific fuel consumption and heat rate were determined and plotted using Excel Software as shown in Figures 2-6 respectively while Figure 7 shows the effect of the heat rate on the thermal efficiency.

\subsection{Discussion}

Figure 2 represents the effect of ambient temperature on the power output. It shows

Table 1. Design parameters and their values.

\begin{tabular}{cccc}
\hline S/N & Parameters & Units & Design Data \\
1 & Power Output & $\mathrm{MW}$ & 25.0 \\
2 & Thermal Efficiency & $\%$ & 26.6 \\
3 & Heat Rate & $\mathrm{Kcal} / \mathrm{W} \cdot \mathrm{h}$ & 2.833 \\
4 & Specific Fuel Consumption & $\mathrm{Kg} / \mathrm{KW} \cdot \mathrm{h}$ & 0.308 \\
5 & Ambient Temperature & ${ }^{\circ} \mathrm{C}$ & $25.0-45.0$ \\
6 & Specific Heat at Constant Pressure of gas & $\mathrm{KJ} / \mathrm{KgK}$ & 1.155 \\
7 & Specific Heat at Constant Pressure of Air & $\mathrm{KJ} / \mathrm{KgK}$ & 1.005 \\
8 & Isentropic Constants for air & $\mathrm{None}$ & 1.40 \\
9 & Isentropic Constants for gas & $\mathrm{None}$ & 1.33 \\
10 & Mass Flow Rate of air & $\mathrm{Kg} / \mathrm{s}$ & 122.9 \\
\hline
\end{tabular}


Table 2. Turbine working parameters (from January 2012 to January 2013).

\begin{tabular}{|c|c|c|c|c|c|c|c|c|c|c|c|c|c|c|}
\hline $\mathrm{S} / \mathrm{N}$ & $\begin{array}{c}T_{1}^{\circ} \mathrm{C} \\
\text { Ambient } \\
\text { Temperature }\end{array}$ & $\begin{array}{c}T_{2}^{\circ} \mathrm{C} \\
\text { Compressor } \\
\text { Exit } \\
\text { Temperature }\end{array}$ & $\begin{array}{c}T_{3}^{\circ} \mathrm{C} \\
\text { Turbine } \\
\text { Inlet } \\
\text { Temperature }\end{array}$ & $\begin{array}{c}T_{4}^{\circ} \mathrm{C} \\
\text { Exhaust } \\
\text { Temperature }\end{array}$ & $\begin{array}{c}\dot{m}_{f} \\
(\mathrm{~kg} / \mathrm{s}) \\
\text { Fuel } \\
\text { Supply }\end{array}$ & $\begin{array}{l}\dot{W}_{c}(\mathrm{KW}) \\
\text { Compress } \\
\text { or Work }\end{array}$ & $\begin{array}{c}\dot{W}_{T}(\mathrm{KW}) \\
\text { Turbine } \\
\text { Work }\end{array}$ & $\begin{array}{c}\dot{Q}_{\text {Added }} \\
(\mathrm{KW}) \\
\text { Heat } \\
\text { Supplied }\end{array}$ & $\begin{array}{c}\dot{W}_{\text {net }} \\
(\mathrm{KW}) \\
\text { Net } \\
\text { Work }\end{array}$ & $\begin{array}{c}A F R \\
\text { Air } \\
\text { Fuel } \\
\text { Ratio }\end{array}$ & $\begin{array}{c}\eta_{h}(\%) \\
\text { Thermal } \\
\text { Efficiency }\end{array}$ & $\begin{array}{c}S F C \\
(\mathrm{~kg} / \mathrm{KWh}) \\
\text { Specific } \\
\text { Fuel } \\
\text { Consumption }\end{array}$ & $\begin{array}{c}H R \\
(\mathrm{KCal} / \mathrm{W} \cdot \mathrm{h}) \\
\text { Heat Rate }\end{array}$ & $\begin{array}{l}\text { (MW) } \\
\text { Power } \\
\text { Output }\end{array}$ \\
\hline 1 & 25 & 240 & 1017 & 378 & 2.60 & 26,556 & 1670 & 98,002 & 24,886 & 0.485 & 25.39 & 0.298 & 3.94 & 11.14 \\
\hline 2 & 26 & 242 & 1025 & 382 & 2.62 & 26,679 & 1693 & 98,774 & 24,986 & 0.481 & 25.30 & 0.300 & 3.95 & 11.14 \\
\hline 3 & 27 & 244 & 1032 & 384 & 2.64 & 26,803 & 1719 & 99,420 & 25,084 & 0.478 & 25.23 & 0.300 & 3.96 & 11.13 \\
\hline 4 & 28 & 246 & 1041 & 385 & 2.66 & 26,926 & 2015 & 100,319 & 24,911 & 0.474 & 24.83 & 0.305 & 4.03 & 11.13 \\
\hline 5 & 29 & 247 & 1045 & 387 & 2.67 & 26,926 & 2029 & 100,706 & 24,897 & 0.472 & 24.72 & 0.306 & 4.05 & 11.13 \\
\hline 6 & 30 & 248 & 1049 & 390 & 2.68 & 26,926 & 2040 & 101,093 & 24,886 & 0.470 & 24.62 & 0.308 & 4.06 & 11.13 \\
\hline 7 & 31 & 250 & 1054 & 392 & 2.69 & 27,050 & 2054 & 101,479 & 24,996 & 0.470 & 24.60 & 0.308 & 4.06 & 11.12 \\
\hline 8 & 32 & 254 & 1092 & 394 & 2.80 & 27,420 & 2257 & 105,863 & 25,163 & 0.449 & 23.77 & 0.319 & 4.20 & 11.11 \\
\hline 9 & 33 & 257 & 1101 & 388 & 2.82 & 27,667 & 2322 & 106,638 & 25,345 & 0.445 & 23.77 & 0.319 & 4.20 & 11.10 \\
\hline 10 & 34 & 258 & 1127 & 400 & 2.90 & 27,667 & 2435 & 109,867 & 25,232 & 0.432 & 22.97 & 0.330 & 4.35 & 11.09 \\
\hline 11 & 35 & 260 & 1135 & 389 & 2.92 & 28,451 & 2516 & 110,643 & 25,935 & 0.430 & 23.44 & 0.322 & 4.27 & 11.08 \\
\hline 12 & 36 & 262 & 1156 & 388 & 2.98 & 28,591 & 2643 & 113,099 & 25,948 & 0.420 & 22.94 & 0.330 & 4.36 & 11.07 \\
\hline 13 & 37 & 265 & 1165 & 379 & 3.00 & 28,849 & 2724 & 113,877 & 26125 & 0.418 & 22.94 & 0.330 & 4.36 & 11.04 \\
\hline
\end{tabular}

Table 3. Parameters compared to percentage of design.

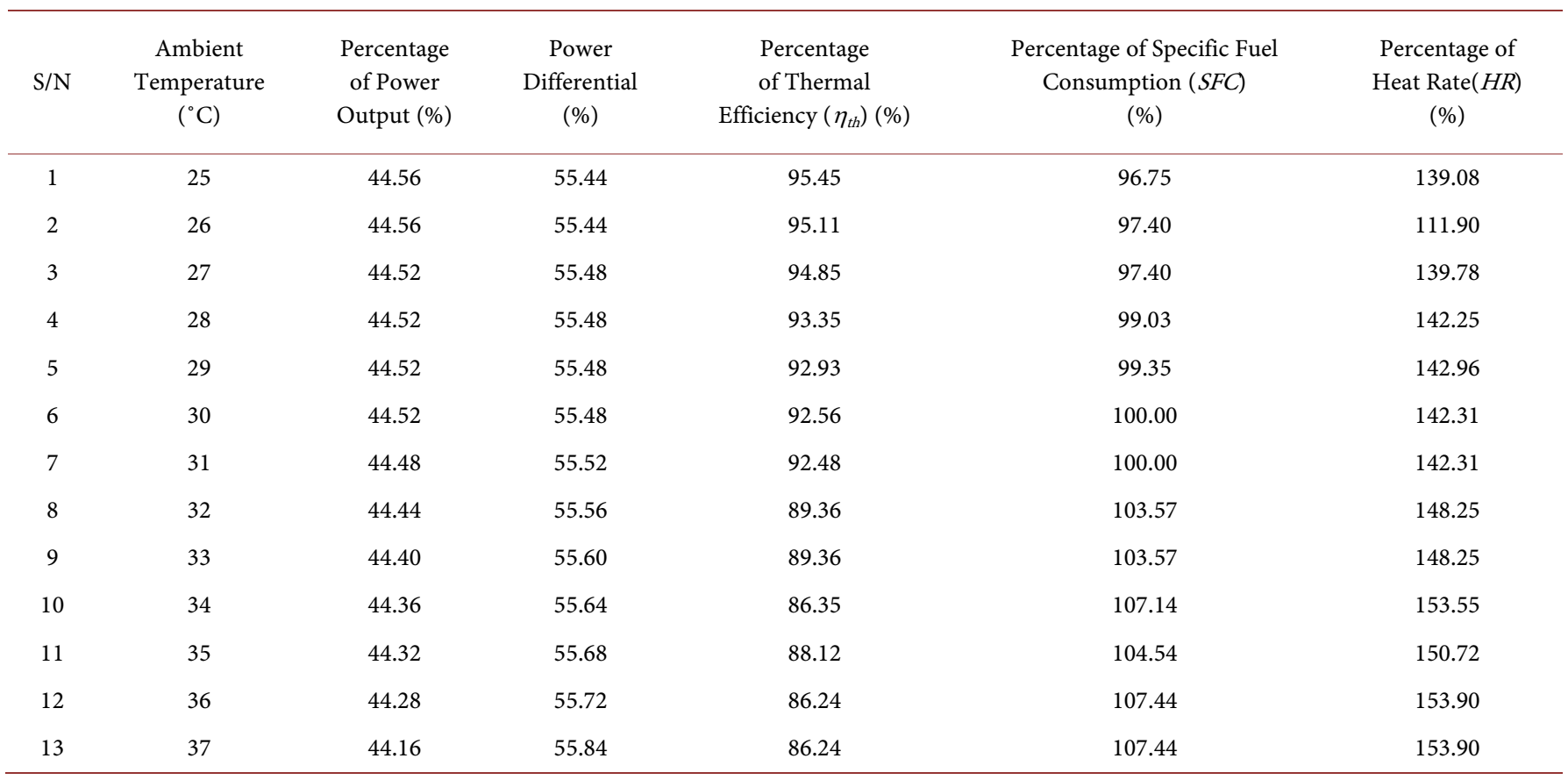

that the power output decreases as the ambient temperature increases. It also shows that as the ambient temperature increases from $29^{\circ} \mathrm{C}$ to $35^{\circ} \mathrm{C}$, the power output decreases from $44.52 \%$ to $44.33 \%$. In real terms, the power output decreases from 4.96 MW to $4.91 \mathrm{MW}$. 


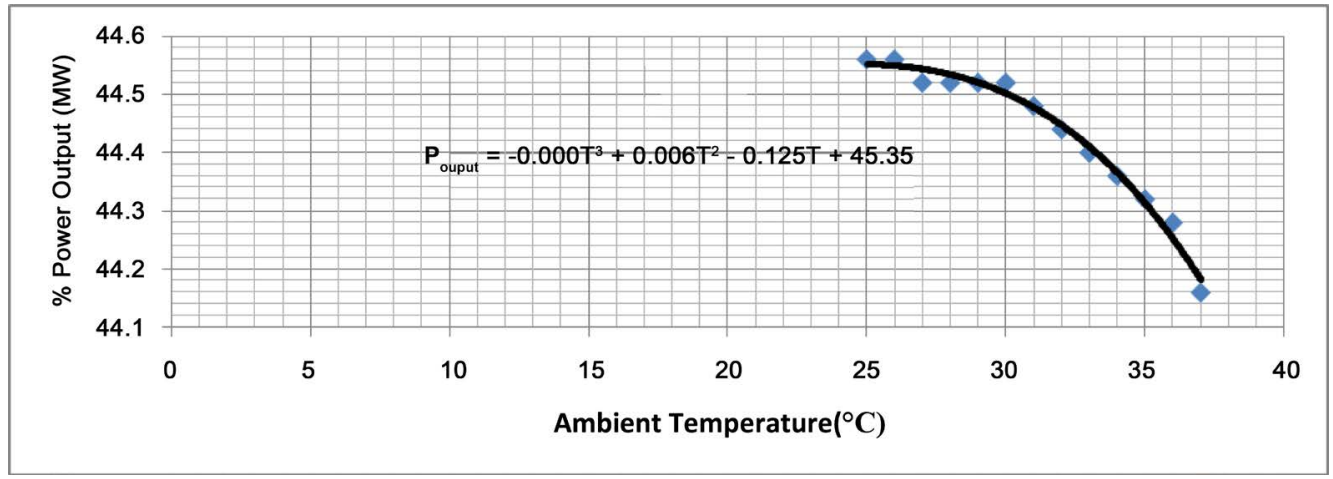

Figure 2. Effect of ambient temperature on the power output.

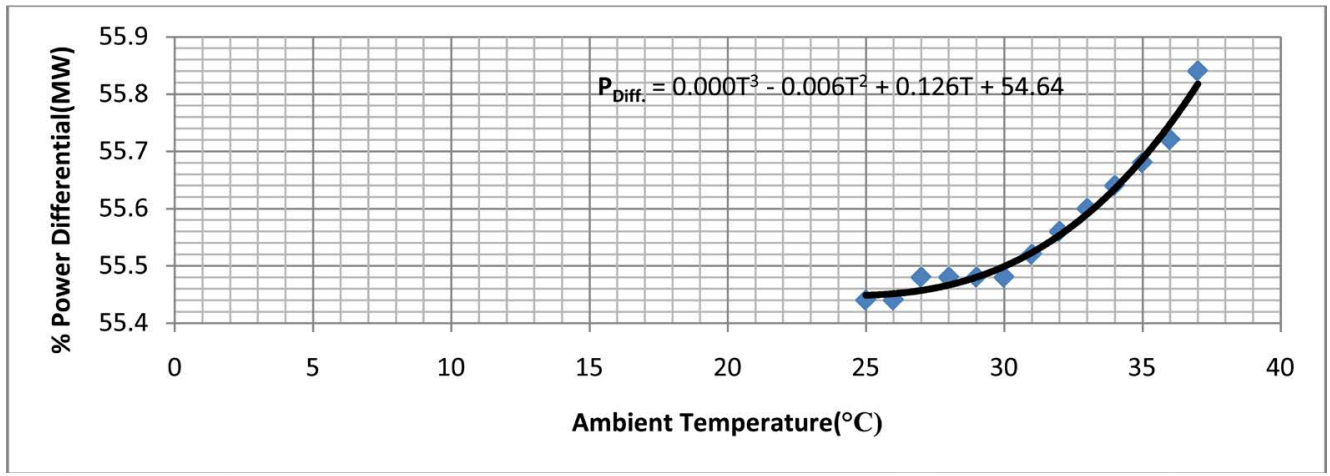

Figure 3. Effect of ambient temperature on the power differential.

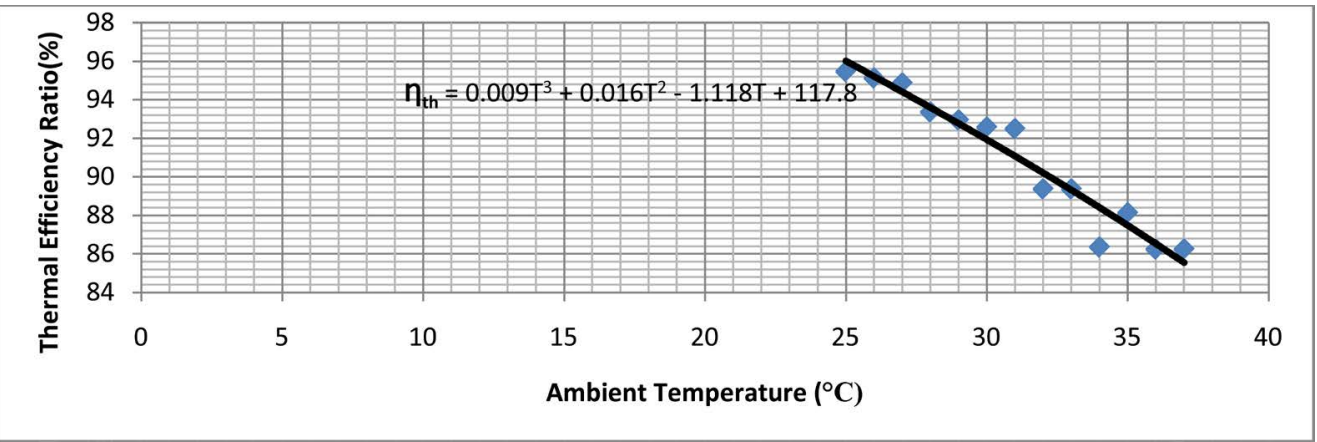

Figure 4. Effect of ambient temperature on the thermal efficiency ratio.

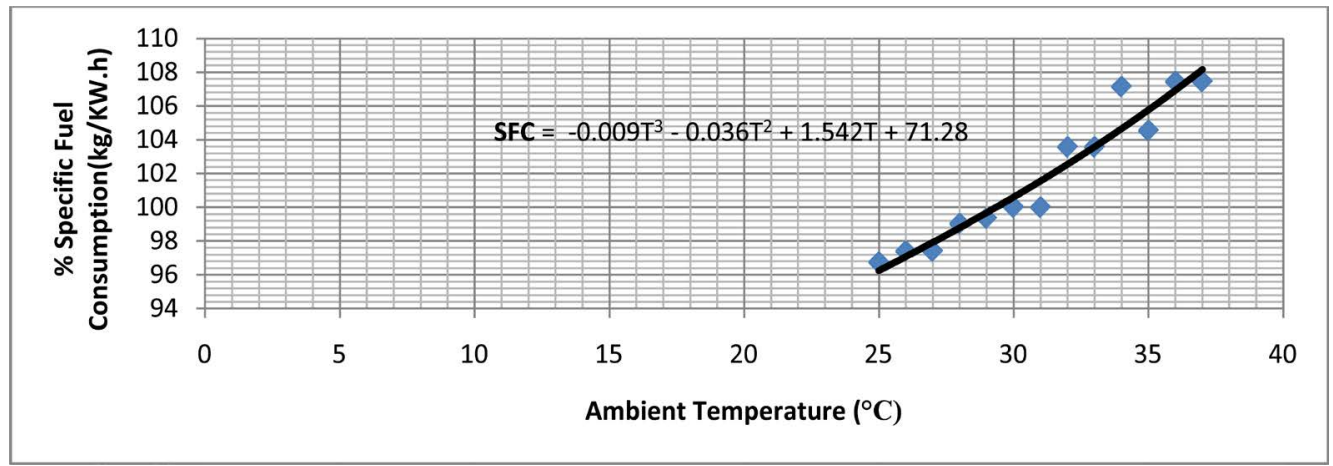

Figure 5. Effect of ambient temperature on the specific fuel consumption. 


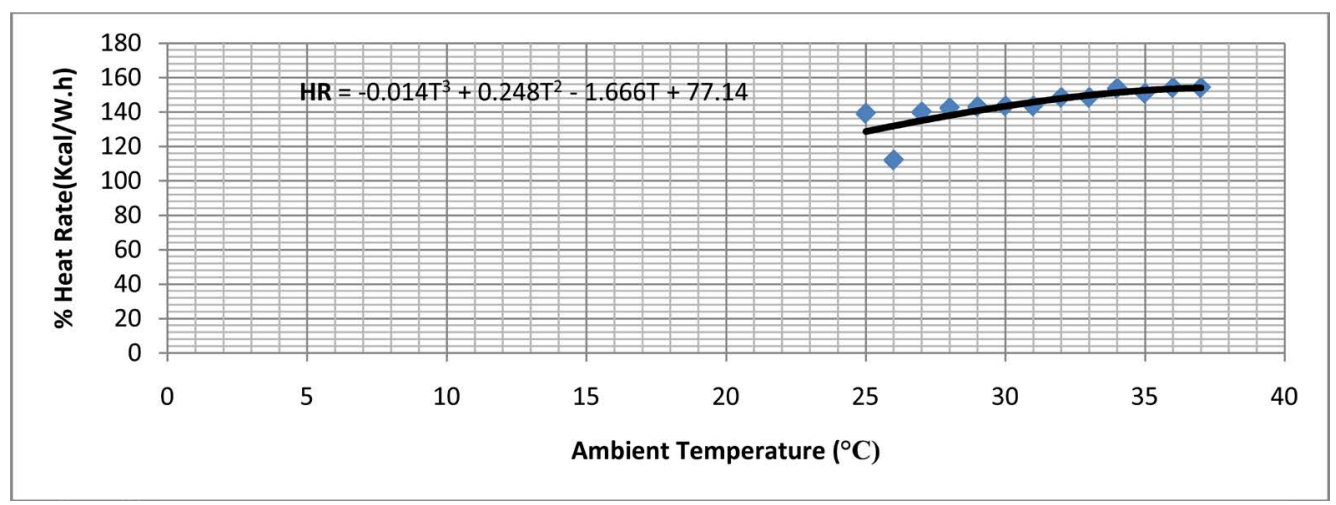

Figure 6. Effect of ambient temperature on the heat rate.

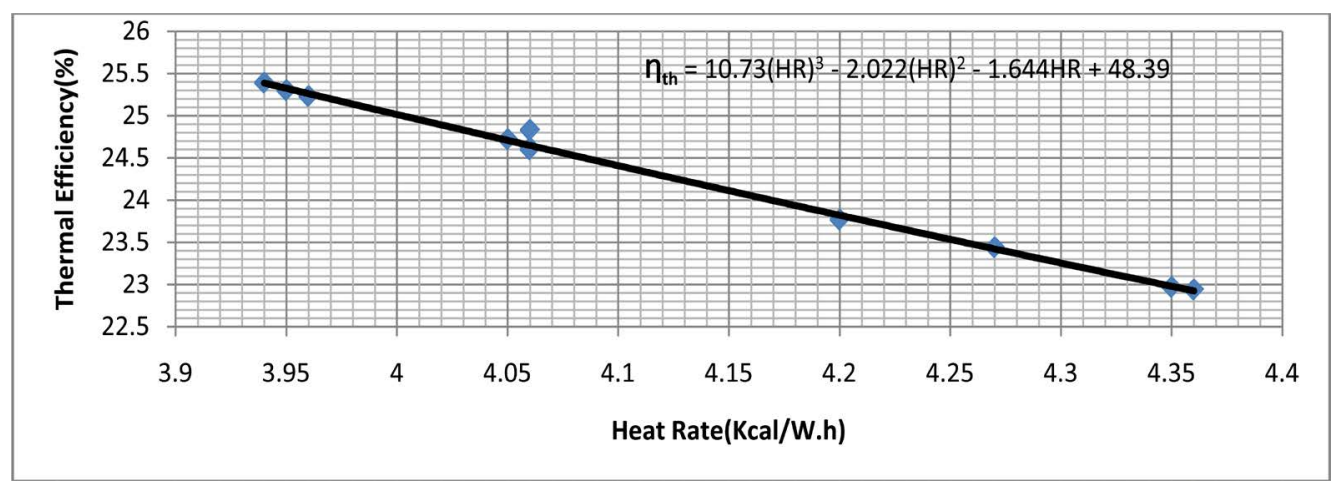

Figure 7. Effect of heat rate on the thermal efficiency.

Figure 3 represents the effect of ambient temperature on the power differential. It shows that the power differential increases as the ambient temperature increases. It also depicts that as the ambient temperature increases from $29^{\circ} \mathrm{C}$ to $35^{\circ} \mathrm{C}$, the power differential increases from $58.44 \%$ to $58.79 \%$ and in real terms, the power drop increases from 6.17 MW to 6.20 MW.

Figure 4 shows the effect of ambient temperature on the thermal efficiency ratio. It shows that the thermal efficiency ratio decreases as the ambient temperature increases. It also illustrates that as the ambient temperatures increases from $28^{\circ} \mathrm{C}$ to $33^{\circ} \mathrm{C}$, the thermal efficiency ratio decreases from $94.60 \%$ to $88.60 \%$. In real terms, the thermal efficiency increases from $23.49 \%$ to $21.06 \%$.

Figure 5 depicts the effect of ambient temperature on the specific fuel consumption. It shows that the specific fuel consumption increases as the ambient temperature increases. It also shows that as the ambient temperature increases from $30^{\circ} \mathrm{C}$ to $33^{\circ} \mathrm{C}$, the specific fuel consumption increases from $98.60 \%$ to $102.80 \%$ and in real terms, the specific fuel consumption increases from $0.304 \mathrm{~kg} / \mathrm{KWh}$ to $0.328 \mathrm{~kg} / \mathrm{KWh}$.

Figure 6 shows the effect of the ambient temperature: compressor inlet temperature on the heat rate. It shows that the heat rate increases as the ambient temperature increases. Figure 6 further shows that as the ambient temperature increases from $30^{\circ} \mathrm{C}$ to $37^{\circ} \mathrm{C}$, the heat rate increases $144 \%$ to $156 \%$. In actual analysis, the heat rate increases from, $5.85 \mathrm{Kcal} / \mathrm{W} \cdot \mathrm{h}$ to $6.80 \mathrm{Kcal} / \mathrm{W} \cdot \mathrm{h}$. 
Finally, Figure 7 represents the effect of the heat rate on the thermal efficiency. It shows that the thermal efficiency decreases as the heat rate increases. Figure 7 also depicts in real terms that as the heat rate increases from $3.94 \mathrm{Kcal} / \mathrm{W} \cdot \mathrm{h}$ to $4.36 \mathrm{Kcal} / \mathrm{W} \cdot \mathrm{h}$, the thermal efficiency decreases from $25.4 \%$ to $22.58 \%$.

\section{Conclusion}

The result of the study shows that the ambient temperature has effect on the performance of the gas turbine and that a $1^{\circ} \mathrm{C}$ rise of the ambient temperature is responsible for the following: $0 \%-0.12 \%$ decrease in the power output, $0 \%-0.12 \%$ increase in the power differential, $0 \%-1.17 \%$ decrease in the thermal efficiency, $0 \%-27.18 \%$ increase in the heat rate and $0 \%-3.57 \%$ increase in the specific fuel consumption.

\section{References}

[1] Khajuria, P.R. and Dubey, S.P. (1992) Gas Turbines and Propulsive Systems. Dhanpat RaiPublication(P) Ltd., New Delhi.

[2] Daiber, P.C. (1996) Performance and Reliability Improvements for MS5001 Gas Turbines. GE Power Systems, Atlanta.

[3] Frank, J.B. (2000) GE Gas Turbine Performance Characteristics. GE Power Systems, Schenectady.

[4] Zactruba, J. (2009) How Does a Gas Turbine Work? From Bright Hub Engineering. http://www.Brighthub.com/engineering/mechanicalengineering/powerplant

[5] Lebele-Alawa, B.T. (2010) Axial-Thrust Responses due to Gas Turbine Rotor Blade Distortions. Journal of Engineering Physics and Thermodynamics, 83, 991-994. https://doi.org/10.1007/s10891-010-0423-2

[6] Lebele-Alawa, B.T. and Asuo, J.M. (2011) Optimization of the System Performance of Gas Turbine Plant. International Journal of Applied Science and Technology, 1, 62-67.

[7] Ibrahim, K.I. and Rahman, M.M. (2012) Effect of Compression Ratio on the Performance of Combined Cycle Gas Turbine. International Journal of Energy Engineering, 2, 9-14. https://doi.org/10.5923/j.ijee.20120201.02

[8] Lebele-Alawa, B.T. and Asuo, J.M. (2013) Influence of the Variation of Power Turbine Inlet Temperature on Overall Turbine Efficiency. International Journal of Engineering and Innovative Technology (IJEIT), 2, 226-229.

[9] Robert, P. and Ogbonnaya, E.A. (2014) Effect of Evaporative Cooling on the Performance of Gas Turbine Plant Operating in Bayelsa State, Nigeria. International Journal on Engineering and Technology, 4, 476-482.

[10] Lebele-Alawa, B.T. and Jo-Appah, V. (2015) Thermodynamic Performance Analysis of a Gas Turbine in an Equatorial Rain Forest Environment. Journal of Power and Energy Engineering, 3, 11-23. https://doi.org/10.4236/jpee.2015.31002

[11] Gordon, R. and Yon, M. (2001) Engineering Thermodynamics (Work and Heat Transfer). Addison Wesley Longman Publishers, Pte Ltd., Singapore.

[12] Eastop, T.D. and Mckonkey, A. (2002) Applied Thermodynamic. 5th Edition, Pearson Publishing, London.

[13] El-Walkil, M.M. (1980) Power Plant Technology. McGraw-Hill Company Inc., London.

[14] Nag, P.K. (2001) Power Plant Engineering. 2nd Edition, McGraw-Hill Publishers Inc., 
United Kingdom.

[15] Ibrahim, T.K., Rahman, M.M. and Abdulla, A.M. (2011) Improvement of Gas Turbine Performance Based on Inlet Air Cooling. International Journal of Physical Sciences, 6, 620-647.

[16] Oyedepo, O.S. and Kilanko, O. (2014) Thermodynamic Analysis of a Gas Turbine Power Plant Modelled with Evaporative Cooler. International Journal of Thermodynamics, 17, 1420. https://doi.org/10.5541/ijot.480 


\section{Nomenclature}

$A F R \quad$ Air Fuel Ratio

$C_{p} \quad$ Specific Heat Capacity of the Product $\mathrm{KJ} / \mathrm{KgK}$

$C_{p a} \quad$ Specific Heat of Air at Constant Pressure $\mathrm{KJ} / \mathrm{KgK}$

$C_{p g} \quad$ Specific Heat of Gas at Constant Pressure $\mathrm{KJ} / \mathrm{KgK}$

$C V \quad$ Calorific Value of the Fuel

$\frac{\mathrm{d} E_{C V}}{\mathrm{~d} t} \quad$ Change in energy within the control volume over time

$\Sigma \quad$ Summation

F $\quad$ Fuel Ratio

$g \quad$ Acceleration due to Gravity $g=9.81 \mathrm{~m} / \mathrm{s}^{2}$

GT Gas Turbine

$h \quad$ Specific Enthalpy KJ/KgK

$H R \quad$ Heat Rate Kcal/KW.h

LHV Lower Heat Value $\mathrm{KJ} / \mathrm{Kg}$

MW Meggawatts

$\dot{m} \quad$ Mass Flow Rate $\mathrm{Kg} / \mathrm{s}$

$\dot{m}_{p} \quad$ Mass Flow Rate of the Product Kg/s

$\dot{m}_{a} \quad$ Mass flow rate of air $\mathrm{Kg} / \mathrm{s}$

$\dot{m}_{g} \quad$ Mass flow rate of gas $\mathrm{Kg} / \mathrm{s}$

$\dot{m}_{f} \quad$ Mass flow rate of fuel $\mathrm{Kg} / \mathrm{s}$

$\eta_{t h} \quad$ Thermal Efficiency $\%$

$\eta_{t s} \quad$ Isentropic Efficiency of Turbine \%

$P \quad$ Pressure bar

$P_{\text {atm }} \quad$ Atmospheric Pressure bar

$P_{\text {Diff. }} \quad$ Power Differential MW

$P_{\text {Output }} \quad$ Power Output MW

$P_{1} \quad$ Compressor Inlet Pressure: Atmospheric Pressure bar

$P_{2} \quad$ Compressor Outlet Pressure bar

$P_{3} \quad$ Turbine Inlet Pressure bar

$P_{t h} \quad$ Thermal Energy MW

$P_{4} \quad$ Turbine Outlet Pressure bar

$\rho_{a} \quad$ Density of Air Kg/m $\mathrm{m}^{3}$

$\dot{Q} \quad$ Quantity of Heat Transfer $\mathrm{KJ} / \mathrm{Kg}$

$Q_{\text {added }} \quad$ Heat Added or Heat Supplied KJ/Kg

$s \quad$ Specific Entropy $\mathrm{KJ} / \mathrm{KgK}$

$S F C \quad$ Specific Fuel Consumption $\mathrm{Kg} / \mathrm{KW} \cdot \mathrm{h}$

$T \quad$ Temperature ${ }^{\circ} \mathrm{C}$ or $\mathrm{K}$

$T_{f} \quad$ Temperature of Fuel ${ }^{\circ} \mathrm{C}$

$T_{1} \quad$ Ambient Temperature ${ }^{\circ} \mathrm{C}$

$T_{2} \quad$ Compressor Exit Temperature ${ }^{\circ} \mathrm{C}$

$\mathrm{T}_{3} \quad$ Turbine Inlet Temperature ${ }^{\circ} \mathrm{C}$ 


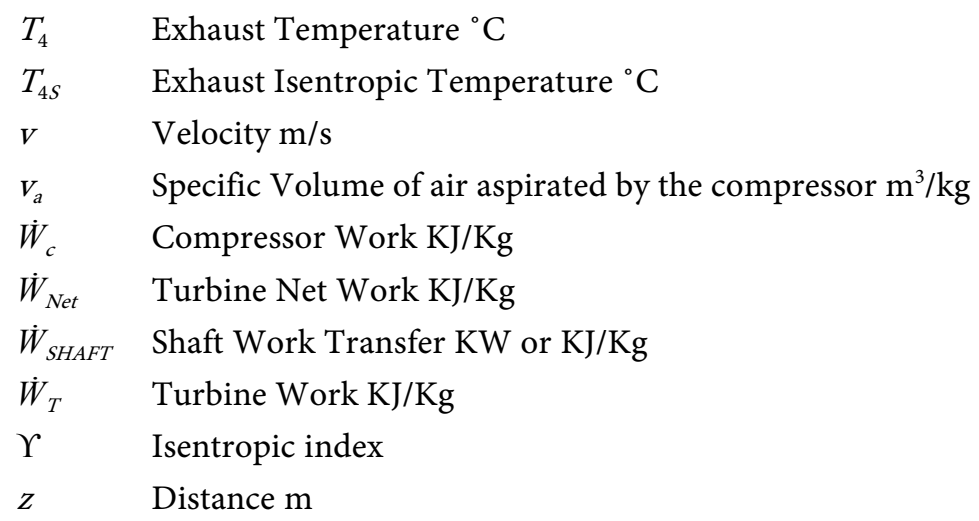

Submit or recommend next manuscript to SCIRP and we will provide best service for you:

Accepting pre-submission inquiries through Email, Facebook, LinkedIn, Twitter, etc. A wide selection of journals (inclusive of 9 subjects, more than 200 journals)

Providing 24-hour high-quality service

User-friendly online submission system

Fair and swift peer-review system

Efficient typesetting and proofreading procedure

Display of the result of downloads and visits, as well as the number of cited articles Maximum dissemination of your research work

Submit your manuscript at: http://papersubmission.scirp.org/

Or contact jpee@scirp.org 